\title{
Pengembangan Penuntun Praktikum Reaksi Reduksi dan Oksidasi Berbasis Bahan Alam dengan Menggunakan Model ADDIE
}

\author{
Ade Wiwit Tahulending ${ }^{* a}$, Rymond Rumampuk $^{a}$, Anderson Aloanis ${ }^{b}$ \\ a Kimia, FMIPA, Universitas Negeri Manado, Minahasa, 95618, Indonesia
}

\begin{tabular}{l} 
I N F O A R T I K E L \\
\hline Diterima 12 November 2019 \\
Disetujui 31 Desember 2019 \\
\hline Key word: \\
ADDIE \\
Practical Guide \\
Natural Materials \\
Redox \\
\hline Kata kunci: \\
ADDIE \\
Penuntun Praktikum \\
Bahan Alam \\
Redoks
\end{tabular}

*e-mail:

adewiwit2297@gmail.com

*Telp: 085241381320

\begin{abstract}
A B S T R A C T
Guidance for practicum is one of the most important conditions in carrying out practicum so that practicum can run well. This study aims to develop a practical guide for redox material based on natural materials using the ADDIE model and to determine the feasibility of the guide developed. Data collection techniques used were interview methods, observation methods, validator questionnaire methods and student response questionnaires. This research was tested in class X IPA of SMA Negeri 2 Tondano with 25 students. Data analysis method used is the analysis of the process or product development and the analysis of the results of the quality of the practical guide. Based on the percentage of the two validators as media experts and material experts the average percentage assessment score was $92.8 \%$ with a very feasible category, while the percentage of overall student response data obtained an assessment score of $81.65 \%$ with the feasibility category is very feasible.
\end{abstract}

\section{A B S T R A K}

Penuntun praktikum termasuk salah satu syarat yang sangat penting dalam melaksanakan praktikum agar praktikum dapat berjalan dengan baik. Penelitian ini bertujuan untuk mengembangkan penuntun praktikum materi redoks berbasis bahan alam dengan menggunakan model ADDIE dan untuk mengetahui kelayakan dari penuntun yang dikembangkan. Teknik pengumpulan data yang digunakan adalah metode wawancara, metode observasi, serta metode angket validator dan angket respon siswa. Penelitian ini diujicobakan di kelas X IPA SMA Negeri 2 Tondano dengan jumlah siswa 25. Metode analisis data yang digunakan adalah analisis proses atau pengembangan produk dan analisis data hasil kualitas penuntun praktikum. Berdasarkan persentase dari kedua validator sebagai ahli media dan ahli materi diperoleh skor penilaian persentase rata-rata 92,8\% dengan kategori kelayakan sangat layak, sedangkan untuk persentase data respon siswa keseluruhan diperoleh skor penilaian 81,65\% dengan kategori kelayakan sangat layak.

\section{Pendahuluan}

Kimia merupakan mata pelajaran yang sangat penting dan harus dipelajari karena kimia sangat berkaitan erat dengan kehidupan sehari-hari dan berhubungan erat dengan alam, sehingga di setiap sekolah menengah ke atas terdapat mata pelajaran kimia agar siswa dapat mengetahui tentang hubungan-hubungan kimia dengan kehidupan sejak dini.

Kimia termasuk dalam ilmu yang tidak dapat dimengerti dan dipahami jika hanya dengan membaca teori-teori saja, namun untuk 
dapat menguasai konsep-konsep yang bersifat abstrak dalam materi-materi kimia diperlukan keterlibatan siswa secara aktif di dalam proses pembelajaran dalam kelas maupun dalam kegiatan praktikum. Kegiatan praktikum ini dapat memberikan siswa pengalaman secara langsung, karena siswa dilibatkan untuk melakukan praktikum langsung, serta menarik kesimpulan dari praktikum yang dilakukan [1]. Kegiatan praktikum dalam laboratorium dapat memberi pengaruh besar terhadap sukses, lancar, dan berhasilnya siswa dalam mempelajari kimia. Siswa dapat mengamati secara langsung proses-proses kimia yang terjadi di alam sekitar dan dapat memecahkan masalah yang terdapat dalam kegiatan praktikum [2].

Proses pembelajaran dengan kegiatan praktikum membutuhkan penuntun agar praktikum terlaksana dengan baik, lancar, dan efektif. Penuntun praktikum merupakan salah satu media pembelajaran dalam kegiatan praktikum yang berisi prosedur-prosedur dalam mengikuti praktikum. Penuntun tersebut dapat berupa buku cetak maupun dalam bentuk lembaran-lembaran yang dibuat sendiri oleh guru kimia. Penggunaan penuntun ini sangat penting agar dapat membantu guru dan siswa dalam kelancaran kegiatan praktikum.

Pada kegiatan praktikum kimia di SMA, siswa-siswa dituntut untuk dapat lebih berperan aktif dalam laboratorium dibawah bimbingan guru dengan adanya penuntun praktikum yang lebih baik dan lengkap. Dalam mengembangkan penuntun praktikum yang baik dan lengkap dibutuhkan model pengembangan salah satunya model pengembangan ADDIE singkatan dari Analysis, Design, Development, Implementation dan Evaluations. Dengan menggunakan model ADDIE dalam mengembangkan penuntun praktikum dapat membuat penuntun praktikum lebih valid dan layak untuk di terapkan dalam proses pembelajaran dengan kegiatan praktikum [3].

Reaksi reduksi dan oksidasi merupakan satu diantara materi kimia di kelas $\mathrm{X}$ yang melibatkan kegiatan praktikum di laboratorium. Materi redoks tidak cukup jika hanya diajarkan teori-teorinya saja tanpa adanya praktikum, oleh karena itu guru dapat melakukan kegiatan praktikum yang menuntut siswa aktif dalam mengikuti pembelajaran dan siswa akan mudah memahami materi redoks tersebut.

Berdasarkan hasil observasi di SMA Negeri 2 Tondano, kurangnya alat dan bahan praktikum di laboratorium serta penuntun praktikum yang tidak lengkap menjadi kendala bagi guru dan siswa untuk melaksanakan kegiatan praktikum. Salah satu upaya yang dapat dilakukan untuk mengatasi kendalakendala tersebut yaitu dengan mengembangkan penuntun praktikum berbasis bahan alam [4]. Penuntun berbasis bahan alam dapat memberikan ilmu dan wawasan kepada guru dan siswa bahwa praktikum kimia dapat terlaksana dengan memanfaatkan bahan-bahan alam yang ada di sekitar kita seperti pada praktikum materi redoks pada reaksi pencoklatan terhadap kentang dan buah pisang, bahan-bahan alam ini sangat mudah untuk ditemukan dan tidak memerlukan biaya yang mahal. Dengan dimanfaatkannya bahanbahan alam yang ada dalam mengembangkan penuntun praktikum, siswa-siswa yang mengikuti kegiatan praktikum akan lebih mudah mengerti dan memahami materi yang diajarkan.

\section{Metode}

Penelitian ini dilaksanakan di kelas X IPA SMA Negeri 2 Tondano pada semester genap tahun ajaran 2018/2019. Penelitian ini termasuk penelitian pengembangan yang menghasilkan produk pengembangan berupa penuntun praktikum materi reaksi reduksi dan oksidasi berbasis bahan alam dengan menggunakan model ADDIE. Rancangan penelitian yang digunakan adalah pengembangan penuntun praktikum ini dilakukan berdasarkan model pembelajaran ADDIE, singkatan dari Analysis, Design, Development, Implementation, and Evaluation. Pada penelitian ini, dari ke lima tahap model ADDIE hanya diberlakukan sampai pada tahap ke empat yaitu Tahap Analisis (Analysis), Tahap Desain (Design), Tahap Pengembangan (Development) dan Tahap Implementasi (Implementation).

Instrumen penelitian yang digunakan dalam penelitian ini adalah angket validator 
dan angket respon siswa. Angket yang digunakan yaitu lembar validator penuntun praktikum oleh dosen dan guru kimia dan lembar angket respon siswa terhadap penuntun praktikum.

Teknik pengumpulan data dalam penelitian ini dilakukan dengan 3 cara, yaitu: metode wawancara, observasi tempat penelitian (lingkungan sekolah dan laboratorium), dan metode angket. Teknik analisis data dalam proses penelitian ini, yaitu menganalisis proses dan pengembangan produk atau mengembangkan penuntun praktikum dan data hasil kualitas penuntun praktikum.

Hasil angket validator dan angket respon siswa dianalisis per item dengan menggunakan rumus:

$$
P=\frac{x}{x i} \times 100 \%
$$

Kategori penuntun praktikum dilihat pada tabel 1.

Tabel 1. Kategori kelayakan penuntun praktikum

\begin{tabular}{cc}
\hline Skor Persentase (\%) & Kategori \\
\hline Kurang dari $50 \%$ & Sangat Kurang \\
$50 \%-60 \%$ & Kurang \\
$61 \%-70 \%$ & Cukup Layak \\
$71 \%-80 \%$ & Layak \\
$81 \%-100 \%$ & Sangat Layak \\
\hline
\end{tabular}

Skor persentase tersebut menunjukkan kualitas Buku Penuntun Praktikum Kimia materi reaksi reduksi dan oksidasi yang telah dikembangkan. Buku Penuntun Praktikum ini akan dikatakan layak jika diperoleh hasil yang berada pada kriteria "Layak" dan "Sangat Layak".

\section{Hasil dan Pembahasan}

Tujuan dalam pengembangan penuntun praktikum ini yaitu agar terbentuknya penuntun praktikum redoks tentang reaksi pencoklatan (Browning) berbasis bahan alam yang layak sesuai dengan kategori kelayakan pengembangan penuntun praktikum. Dalam mengembangkan penuntun praktikum ini digunakan model ADDIE dengan langkahlangkah sebagai berikut:

\section{Tahap Analisis (Analysis)}

Pada tahap analisis ini, ada beberapa analisis yang peneliti lakukan meliputi: analisis kurikulum, analisis materi, analisis karakteristik dari peserta didik, dan perumusan tujuan.

\section{Analisis Kurikulum}

Pada tahap ini, peneliti melakukan analisis pada kurikulum 2013 untuk menggunakan kurikulum 2013 dalam proses pengembangan penuntun praktikum dan pada saat melalukan penelitian. Analisis ini digunakan untuk melihat dan mengetahui Kompetensi Dasar (KD) dan Kompetensi Inti (KI) yang sesuai untuk digunakan dalam pengembangan penuntun praktikum. Pada pengembangan penuntun praktikum ini, digunakan buah pisang dan kentang dalam melihat reaksi pencoklatan dan pencegahan terhadap reaksi pencoklatan. Buah apel digantikan oleh buah pisang dan kentang agar lebih mudah didapat dan harganya lebih terjangkau, buah apel di sekitar daerah Tondano dinilai lebih mahal dibandingkan buah pisang dan kentang.

\section{Analisis Materi}

Pada tahap ini, peneliti melakukan analisis terhadap materi yang ada di sekolah penelitian dan memilih materi yang relevan yang akan digunakan dalam praktikum. Setelah peneliti selesai menganalisis materi, peneliti memilih materi yang akan digunakan dalam penuntun praktikum yaitu materi reaksi reduksi dan oksidasi tentang subpokok materi reaksi pencoklatan (Browning).

\section{Analisis Karakteristik Peserta Didik}

Pada tahap ini, peneliti melakukan analisis karakteristik pada peserta didik. Karakteristik peserta didik harus sesuai dengan proses pembelajaran dan penelitian yang akan dilakukan oleh peneliti. Ada beberapa hal yang dilakukan untuk mengetahui atau menganalisis karakter peserta didik, antara lain: kemampuan dalam bekerja sama sesama peserta didik, kemampuan akademik individu dari peserta didik, serta pengalaman belajar dari peserta didik. Hasil analisis terhadap karakteristik peserta didik yaitu peserta didik kelas X IPA dalam bekerja sama telah baik, kemampuan 
akademik individu peserta didik yang baik, dan pemberian materi reaksi reduksi dan oksidasi yang telah diberikan kepada peserta didik agar lebih mengenal dan memahami tentang materi redoks.

\section{Perumusan Tujuan}

Dalam menyusun penuntun praktikum, tujuan dari penuntun praktikum harus dirumuskan terlebih dahulu. Setelah dilakukan rumusan, maka tujuan yang digunakan dalam penuntun praktikum ini yaitu pada materi redoks tentang reaksi pencoklatan (Browning) siswa dapat melakukan percobaan yang berbasis bahan alam dan berhubungan erat dengan kehidupan sehari-sehari seperti: siswa dapat melakukan percobaan untuk mengamati proses terjadinya reaksi redoks terhadap buah dan sayur melalui reaksi pencoklatan (Browning) dan siswa dapat mengetahui pengaruh perendaman buah dan sayur dalam larutan garam dan larutan cuka terhadap pencegahan reaksi pencoklatan (Browning).

\section{Tahap Desain (Design)}

Pada tahap desain ini, peneliti melakukan rancangan atau desain terhadap penuntun praktikum berdasarkan atau sesuai dengan tujuan dari praktikum ini dan sesuai dengan materi dalam kurikulum 2013. Ada beberapa hal yang dilakukan peneliti dalam tahap desain ini, yaitu sebagai berikut:

\section{a. Penyusunan Penuntun Praktikum}

Penyusunan penuntun praktikum ini disusun berdasarkan hasil dari tahap analisis. Peneliti memilih untuk membuat penuntun praktikum materi redoks tentang reaksi pencoklatan (Browning) karena sesuai dengan tanggapan siswa yang sangat tertarik untuk melakukan praktikum dengan bahan-bahan alam yang mudah siswa-siswa mengerti dan sangat mudah untuk didapat. Penuntun praktikum inilah yang nanti akan digunakan dalam pembelajaran kimia setelah melalui tahap-tahap pembuatan penuntun praktikum.

b. Pemilihan Alat dan Bahan yang Sesuai Tujuan

Pemilihan alat dan bahan untuk penuntun praktikum ini, peneliti memilih alat yang mudah untuk didapat dan ada dilaboratorium sekolah agar siswa-siswa lebih mudah mengerti serta peneliti memilih bahan-bahan alam yang mudah untuk didapat dan juga lebih murah serta siswa-siswa lebih mudah tertarik untuk mengikuti praktikum.

\section{c. Pemilihan Format Penuntun Praktikum \\ Sebelum menyusun penuntun praktikum, lebih baik disusun format penuntun praktikum agar selama penyusunan penuntun praktikum menjadi lebih muda.}

\section{Tahap Pengembangan (Development)}

Tabel 2. Data angket validator 1 panelis media

\begin{tabular}{cc}
\hline No Item & Skor Per Item \\
\hline 1 & 4 \\
2 & 3 \\
3 & 4 \\
4 & 3 \\
5 & 3 \\
6 & 4 \\
7 & 4 \\
Jumlah & 25 \\
Persentase & $89,2 \%$ \\
Kategori & Sangat Baik \\
\hline
\end{tabular}

Tabel 3. Data angket validator 2 panelis materi

\begin{tabular}{cc}
\hline No Item & Skor Per Item \\
\hline 1 & 4 \\
2 & 4 \\
3 & 4 \\
4 & 3 \\
5 & 4 \\
6 & 4 \\
7 & 4 \\
Jumlah & 27 \\
Persentase & $96,4 \% \%$ \\
Kategori & Sangat Baik \\
\hline
\end{tabular}

Dalam proses pengembangan penuntun praktikum, ada beberapa kali mengalami perubahan terhadap isi dari penuntun praktikum agar bisa menjadi produk yang baik dan benar. Perubahan tersebut dilakukan oleh 2 validator yang meliputi validator media dan validator materi, dengan nilai yang diperoleh berturut-turut adalah $89,2 \%$ dan $96,4 \%$. 
Kemudian nilai dari kedua validator tersebut dirata-ratakan menjadi 92,8\% dengan kategori sangat layak.

Tabel 4. Skor persentase rata-rata

\begin{tabular}{ccc}
\hline No. & Item & Skor persentase \\
\hline 1. & Validator 1 & $89,2 \%$ \\
2. & Validator 2 & $96,4 \%$ \\
Persentase Rata-rata & $92,8 \%$ \\
\hline
\end{tabular}

Tahap Implementasi (Implementation)

Setelah tahap pengembangan, produk penuntun praktikum kimia yang telah dikembangkan dan menghasilkan penuntun yang baik dan layak sesuai dengan pendapat validator terhadap penuntun praktikum diimplementasikan secara nyata di dalam kelas penelitian. Praktikum dilakukan di laboratorium sekolah sesuai dengan isi penuntun praktikum yaitu penuntun praktikum materi redoks tentang reaksi pencoklatan (Browning). Siswa-siswa yang terlibat dalam penelitian diberi angket untuk menilai penuntun praktikum yang telah peneliti kembangkan.

Setelah penuntun praktikum yang telah dikembangkan diimplementasikan secara nyata di kelas penelitian, peneliti menghitung hasil data angket respon seluruh siswa terhadap penuntun praktikum. Hasil yang diperoleh akan membantu peneliti untuk mengetahui apakah penuntun praktikum yang telah peneliti kembangkan dan yang telah diimplementasikan di sekolah telah sesuai dan memenuhi kategori kelayakan penuntun praktikum. Responden pada penelitian ini berjumlah 25 siswa kelas X IPA. Dari hasil perhitungan keseluruhan data hasil angket respon siswa, maka dirata-ratakan secara keseluruhan nilai presentasi dari 25 siswa adalah $81,65 \%$. Skor ini termasuk dalam kategori "sangat layak".

\section{Kesimpulan}

Berdasarkan hasil penelitian disimpulkan bahwa penuntun praktikum berbasis bahan alam telah dikembangkan sesuai dengan model Analysis, Design, Development, Implementation, and Evaluation (ADDIE). Kelayakan penuntun praktikum ditinjau dari validasi dosen dan guru kimia sebagai validator, serta dari angket respon siswa terhadap penuntun praktikum. Hasil skor rata-rata persentase validator kelayakan penuntun praktikum selama tahap pengembangan adalah $92,8 \%$ yang dikategorikan "sangat layak" dan skor presentase kelayakan penuntun praktikum setelah dilakukan implementasi di sekolah adalah $81,65 \%$ yang dikategorikan "sangat layak" atau valid sehingga penuntun praktikum ini layak untuk digunakan dalam proses pembelajaran kimia.

\section{Daftar Pustaka}

1. Zulaiha, Z.; Hartono, H.; Ibrahim, A. R., Pengembangan buku panduan praktikum kimia hidrokarbon berbasis keterampilan proses sains di sma. Jurnal Penelitian Pendidikan Kimia: Kajian Hasil Penelitian Pendidikan Kimia 2014, 1, (1), 87-93.

2. Wulandari, N.; Vebrianto, R. In Studi Literatur Pembelajaran Kimia Berbasis Masalah ditinjau dari Kemampuan Menggunakan Laboratorium Virtual, Seminar Nasional Teknologi Informasi Komunikasi dan Industri, 2017; pp 709715.

3. Irmi, N.; Rahmayani, R. F. I., Pengembangan Penuntun Praktikum Kimia Dasar II Berbasis Inkuri Terbimbing Pada Materi Reaksi Redoks dan Elektrokimia. Jurnal Ilmiah Mahasiswa Pendidikan Kimia 2017, 2, (1).

4. Mastura, M.; Mauliza, M.; Nurhafidhah, N., Desain Penuntun Praktikum Kimia Berbasis Bahan Alam. Jurnal IPA \& Pembelajaran IPA 2017, 1, (2), 203-212. 